\title{
PENATAAN SISTEM JALUR PEJALAN KAKI DI UNIVERSITAS NEGERI YOGYAKARTA
}

\author{
Muhammad Agphin Ramadhan ${ }^{1}$, Galeh Nur Indriatno Putra Pratama ${ }^{2}$, Retna Hidayah ${ }^{3}$ \\ 1Jurusan Pendidikan Teknik Sipil, FT, UNJ \\ 2,3Jurusan Pendidikan Teknik Sipil dan Perencanaan, FT-UNY \\ Email: agphinramadhan@gmail.com
}

\begin{abstract}
This study aims to: 1) determine the zoning for pedestrian ways; 2) determine the type of pedestrian ways in UNY; 3) to identify problems and solutions related to pedestrian ways in UNY. The method used in this research is descriptive with quantitative approach, by comparing the standard criteria for open space with the condition of reality. The technique of collecting data through observation and measurement of the dimensions of buildings and open spaces using the assistance planimeter website. Basic physical reviews grouping zones through which the road that separates the faculty contained in UNY. The results showed that: 1) zoning is physically in the Campus UNY consists of six zones, namely: Zone A (FT, LPPMP, LPPM), Zone B (FE, FIS, Dean Faculty, Kopma, PPs Lama, FIP), zone C (FBS, Science Faculty, Masjid Mujahideen), zone D (GOR UNY and vicinity), zone E (Stadiums, Tennis Court, FIK), and zone F (Rector, New PPS); 2) in real terms, there are four types of pedestrian ways in UNY, namely: Type 1 (separated), Type 2 (integration), Type 3 (dominant car), and Type 4 (corridor); 3) alternative solutions for problems of special dimensions and availability (level of service) the dimensions sidewalk pavement is in zone $B$ is not ideal, while the sidewalks in zone $A$ is sufficient available.
\end{abstract}

Keywords: Pedestrian, Sidewalk, Yogyakarta State University.

\begin{abstract}
ABSTRAK
Kajian ini bertujuan untuk: 1) mengetahui pembagian zona untuk pedestrian ways; 2) mengetahui tipe pedestrian ways di UNY; 3) mengetahui permasalahan dan solusi yang berhubungan dengan pedestrian ways di UNY. Metode yang digunakan dalam kajian ini adalah deskriptif melalui pendekatan kuantitatif, dengan cara membandingkan kriteria standar ruang terbuka dengan kondisi realita. Teknik pengumpulan data melalui observasi dan pengukuran dimensi bangunan serta ruang terbuka menggunakan bantuan website planimeter. Dasar pengelompokkan zona melalui tinjauan fisik yaitu jalan yang memisahkan beberapa Fakultas yang terdapat di UNY. Hasil kajian menunjukkan bahwa: 1) pembagian zona secara fisik di kawasan Kampus UNY terdiri dari 6 zona, yaitu: Zona A (FT, LPPMP, LPPM), Zona B (FE, FIS, Dekanat FMIPA, Kopma, PPs Lama, FIP), Zona C (FBS, FMIPA, Masjid Mujahiddin), Zona D (GOR UNY dan sekitarnya), Zona E (Stadion, Lapangan Tenis, FIK), dan Zona F (Rektorat, PPs Baru); 2) secara riil, ada 4 tipe pedestrian ways di UNY, yaitu: Tipe 1 (separated), Tipe 2 (integration), Tipe 3 (car dominant), dan Tipe 4 (corridor); 3) alternatif solusi atas permasalahan khusus dimensi dan ketersediaan (tingkat pelayanan) trotoar yaitu dimensi trotoar yang berada di zona B belum ideal, sedangkan trotoar pada zona A sudah cukup tersedia.
\end{abstract}

Kata kunci: Pedestrian, Trotoar, Universitas Negeri Yogyakarta.

\section{PENDAHULUAN}

Sebagai salah satu kampus besar di Provinsi D.I. Yogyakarta, Universitas Negeri Yogyakarta secara fisik telah mengalami perkembangan pesat dari waktu ke waktu. Pengembangan kegiatan akademik yang ditandai dengan INERSIA, Vol. XIV No. 1, Mei 2018 bertambahnya fakultas, jurusan, dan program studi serta bertambahnya mahasiswa setiap tahun menjadi bukti bahwa kawasan UNY telah berubah dari kawasan yang berada di pinggiran kota seperti yang dirasakan beberapa dekade lalu kini menjadi kawasan urban. Menurup Konsep Site Plan UNY (2005 - 2010), tata 
ruang fisik kampus UNY telah dibuat dua kali, dituangkan dalam Rencana Induk Pengembangan (RIP) 1981-1991 dan RIP 1991-2001. Perbedaan yang menonjol dari dua RIP tersebut terutama terletak pada peletakan unit-unit fakultas. Dalam RIP 1991-2001, FIP berada di FBS lama bagian selatan, FIS berada seperti sekarang, FMIPA berada seperti sekarang, FIK di bagian selatan sampai Kuningan, FBS di bagian barat tanpa ISI dan tempat lama bagian utara dan FT seperti sekarang.

Selanjutnya berdasarkan konsep Urban Design menurut Shirvani (1985) terdapat 8 elemen Urban Design, yaitu: Tata Guna Lahan (Land Use), Bentuk dan Massa Bangunan (Building form and massing), Sirkulasi dan Parkir (Circulation and parking), Ruang Terbuka(Open space), Area Pedestrian (Pedestrian ways), Aktivitas Pendukung (Activity Support), Tanda-tanda (Signage), dan Preservasi (Preservation). Dari kedepalan elemen di atas, laporan ini memfokuskan pada elemen Area Pedestrian (Pedestrian ways). Area Pedestrian (Pedestrian ways) adalah area yang sengaja disediakan untuk jalur pejalan kaki. Pada umumnya, trotoar dan pedestrian ways di kawasan perkotaan di Indonesia tereduksi oleh pelanggaranpelanggaran tata bangunan seperti KDB/ KLB. Pelanggaran-pelanggaran ini terjadi akibat kebutuhan kegiatan perkotaan yang tidak diimbangi dengan keserasian penataan ruang-ruang kota. Selain itu, pedestrian ways belum mendapat perhatian yang cukup baik oleh pihak yang terkait. Hal ini dibuktikan dibiarkannya pemanfaatan pedestrian ways menjadi tempat parkir, tempat berjualan, dan digunakan oleh pengendara bermotor, belum lagi dengan kondisi jalur yang rusak.

Pada hakikatnya, aktivitas pejalan kaki bertujuan untuk menempuh jarak sesingkat mungkin antara satu tempat dengan tempat yang lain dengan nyaman dan aman dari gangguan

(kriminalitas/kejahatan, kepadatan lalu-lintas, dan lain-lain). Selain itu para pejalan kaki ingin mendapatkan "sesuatu" pada saat sedang menempuh perjalanan ke suatu tempat tujuan yang tidak bisa dilakukan dengan menggunakan moda transportasi. Namun dengan beberapa permasalahan seperti disebutkan di atas, tujuan dari pedestrian ways tidak dapat tercapai secara maksimal.

Pada kenyataannya, kawasan Kampus UNY sudah tersedia pedestrian ways di beberapa titik, seperti di bagian utara Koperasi Mahasiswa, bagian selatan Museum Pendidikan, di bagian selatan Gedung LPPMP, di bagian barat Lapangan Tenis, dan di beberapa titik lainnya. Tersedianya fasilitas ini menunjukkan pihak kampus sudah memiliki perhatian yang baik terhadap pejalan kaki. Oleh karena itu untuk menunjang fasilitas tersebut dibutuhkan sistem pedestrian ways yang ideal dan tertata dengan baik sehingga dapat memaksimalkan penggunaan pedestrian ways. Dengan adanya penataan sistem pedestrian ways di Kawasan Kampus UNY diharapkan tujuan aktivitas pejalan kaki, khususnya mahasiswa dapat tercapai (Pratama, 2016).

Pedestrian berasal dari bahasa Yunani pedos yang berarti kaki, sehingga pedestriandapat diartikan sebagi pejalan kaki atau orang yang berjalankaki, sedangkanways/ jalan merupakan media diatas bumi yang memudahkan manusia dalamberjalan, Maka pedestrian dalam hal ini memiliki arti pergerakan atau perpindahan orang atau manusia dari satu tempat sebagai titik tolak ke tempat lain sebagai tujuan dengan menggunakan moda jalan kaki. Atau secara harfiah, pedestrian berarti person walking in the street, yang berarti orang yang berjalan di jalan.

Shirvani (1985) dan Linch (1987) berpendapat, pedestrian merupakan bagian dari public space dan merupakan aspek penting sebuah urban space, baik 
Penataan Sistem Jalur... (Muhammad Aghpin/ hal. 101 - 117)

berupa square (lapangan-open space) maupun street (jalan-koridor).Shirvani (1985) menjelaskan lebih lanjut bahwa pedestrian ways merupakan elemen perancangan kota yang penting, yaitu membentuk hubungan antar aktivitas pada suatu lokasi.Pedestrian ways/ side walkberarti jalur pejalan kaki yang mengambil bagian dari jalan kendaraan atau jalur yang terpisah khusus untuk pejalan kaki saja, tetapi ada jalur pejalan kaki yang digunakan bersama-sama dengan jalur sepeda. (Ogden, 1996).

Berdasarkan Pedoman Tata Cara Perencanaan Fasilitas Pejalan Kaki di Kawasan Perkotaan Departemen PU (1995) dapat dijelaskan, pedestrian waysatau jalur pejalan kaki adalah jalur yang disediakan untuk pejalan kaki guna memberikan pelayanan kepada pejalan kaki sehingga dapat meningkatkan kelancaran, keamanan, dan kenyamanan pejalan kaki tersebut. Zona pejalan kaki (pedestrian) adalah area yang diperuntukkan untuk jalur pejalan kaki. Zona pejalan kaki terdiri dari beberapa bagian yaitu zona bagian depan gedung, zona penggunaan bagi pejalan kaki, zona tanaman/perabot, dan zona pinggir jalan (Pedoman Penyediaan dan Pemanfaatan Prasarana dan Sarana Ruang Pejalan Kaki di Perkotaan Dept.PU, 2012). Dengan demikian, dapat disimpulkan bahwa pedestrian ways/ jalur pejalan kaki adalah area berupa jalur yang digunakan oleh pejalan kaki sebagai penghubung dalam melakukan suatu aktivitas di suatu lokasi.

Rubenstein (1992) dapat dijelaskan, terdapat beberapa variasi dari pedestrian ways/ pedestrian mall. antara lain: enclosed mall, full mall, transit mall, dan semi mall. Berikut ini adalah penjelasan dari masingmasing tipe pedestrian mall: (1) Enclosed Pedestrian Mall. Merupakan kawasan khusus pejalan yang bertutup (beratap) untuk melindungi pejalan dari cuaca dingin/salju. Konsepnya menyerupai pusat perbelanjaan di pinggir (suburban shopping mall) yang dapat beropreasi setiap musim dan biasanya diterapkan di daerah beriklim dingin dan 4 musim. Mall ini memerlukan biaya yg cukup mahal. (2) Full Pedestrian Mall. Tipe mall yang diciptakan dengan cara menutup jalan yang tadinya digunakan untuk kendaraan kemudian mengubahnya menjadi kawasan khusus pejalan dengan menambahkan trotoar, perabot jalan, pepohonan, air mancur, dan sebagainya. Pedestrian mall jenis ini biasanya memiliki karakter tertentu dan membantu dalam membangun citra pusat kota. (3) Transit Pedestrian Mall. Tipe mall yang dibangun dengan mengalihkan lalu-lintas kendaraan dari suatu ruas jalan dan hanya angkutan umum yang boleh melalui jalan tersebut. Trotoar bagi pejalan diperlebar, parkir di tepi jalan (on-street parking) dilarang, dan jalan tersebut didesain untuk menciptakan kesan unik pada kawasan pusat kota. (4) Semi Pedestrian Mall. Tipe mall yang dibuat dengan mengurangi parkir pada badan jalan dan arus lalu-lintas yang memalui jalan. Semi pedestrian mall biasanya berada pada jalan utama di sekitar pusat kota. Pada tempat-tempat untuk berjalan kaki terdapat $\mathrm{RTH}$, tempat duduk, penerangan jalan serta elemen estetis lainnya. Mall ini sering diterapkan pada kota-kota besar yang megalami kesulitan menutup total daerah pusat kota dari kendaraan.

Pedoman Penyediaan dan Pemanfaatan Prasarana dan Sarana Ruang Pejalan Kaki di Perkotaan, Dept. PU (2012) dapat dijelaskan, ada 6 tipologi Ruang Pejalan Kaki, yaitu: (1) Ruang Pejalan Kaki di Sisi Jalan (Sidewalk). Ruang pejalan kaki di sisi jalan (sidewalk) merupakan bagian dari sistem jalur pejalan kaki dari tepi jalan raya hingga tepi terluar lahan milik bangunan. 


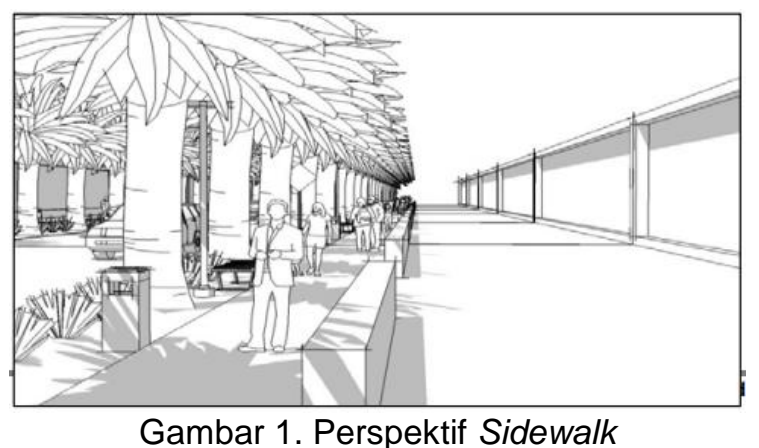

Ruang Pejalan Kaki di Sisi Air (Promenade). sisinya berbatasan dengan badan air. Ruang pejalan kaki yang pada salah satu

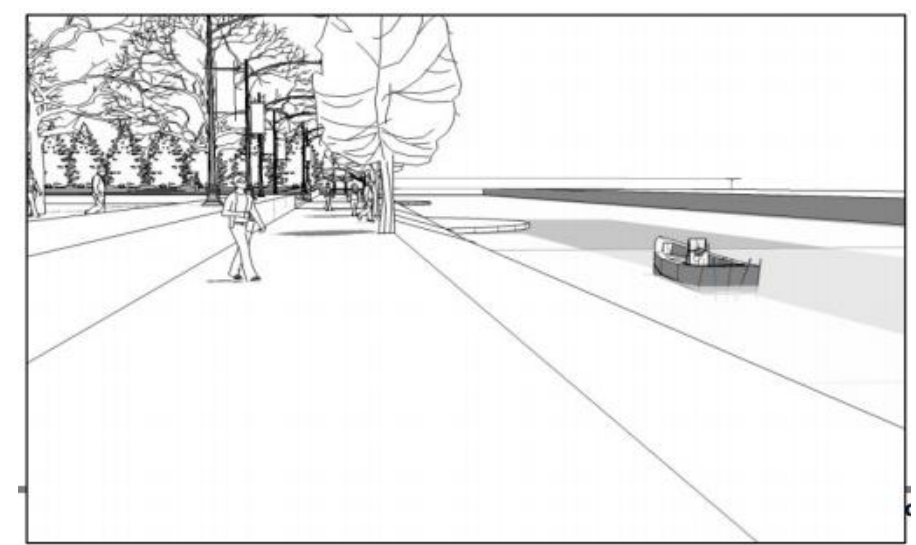

Gambar 2. Perspektif Promenade

Ruang Pejalan Kaki di Kawasan Komersial/ yang berdampingan dengan bangunan Perkantoran (Arcade). Ruang pejalan kaki pada salah satu atau kedua sisinya

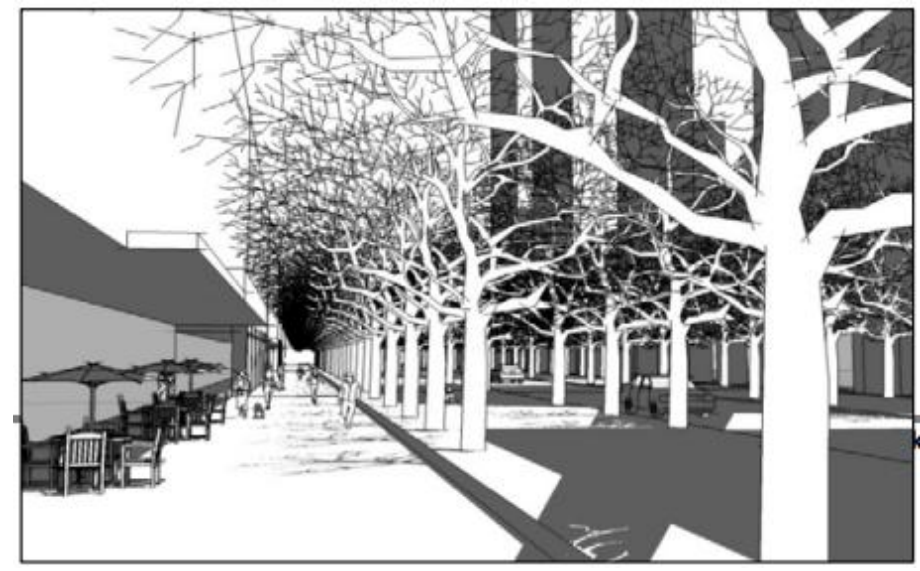

Gambar 3. Perspektif Arcade

Ruang Pejalan Kaki di RTH (Green Pathway). Merupakan ruang pejalan kaki yang terletak diantara ruang terbuka hijau. Ruang ini merupakan pembatas di antara ruang hijau dan ruang sirkulasi pejalan kaki. Area ini menyediakan satu penyangga dari sirkulasi kendaraan di jalan dan memungkinkan untuk dilengkapi dengan berbagai elemen ruang seperti hidran air, kios telepon umum, dan perabot-perabot jalan (bangku- bangku, marka, dan lainlain). 


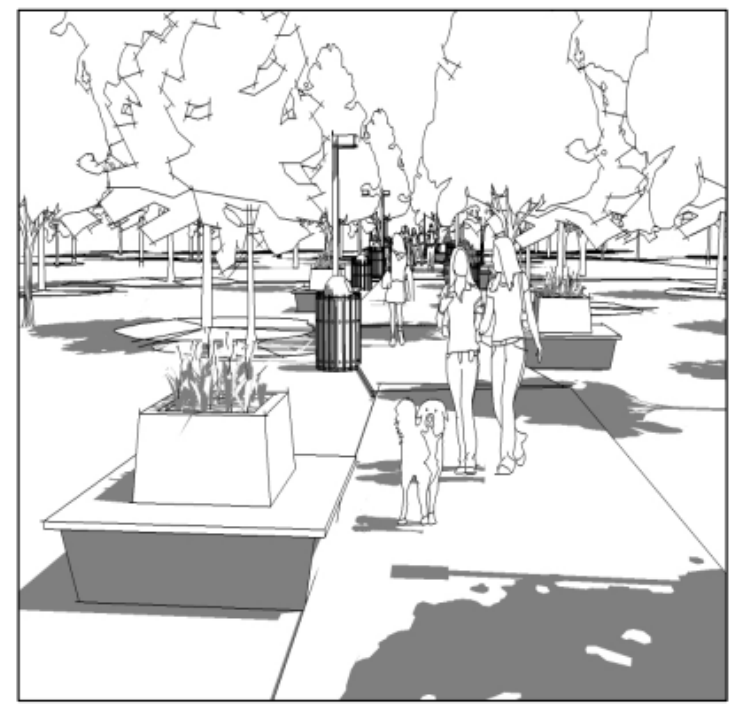

Gambar 4. Perspektif Green Pathway

Ruang Pejalan Kaki di Bawah Tanah (Underground). Ruang pejalan kaki yang merupakan bagian dari bangunan di atasnya maupun jalur khusus pejalan kaki yang berada di bawah permukaan tanah.Ruang pejalan kaki dibawah tanah ini harus terhubung dengan tempat tempat penyeberangan bagi pejalan kaki di bawah tanah. Penyeberangan ini harus mampu dilihat dengan tepat untuk dapat melewatinya. Untuk membantu jarak pandang di malam hari, tempat penyeberangan di bawah jalan harus menyediakan penerangan yang cukup.

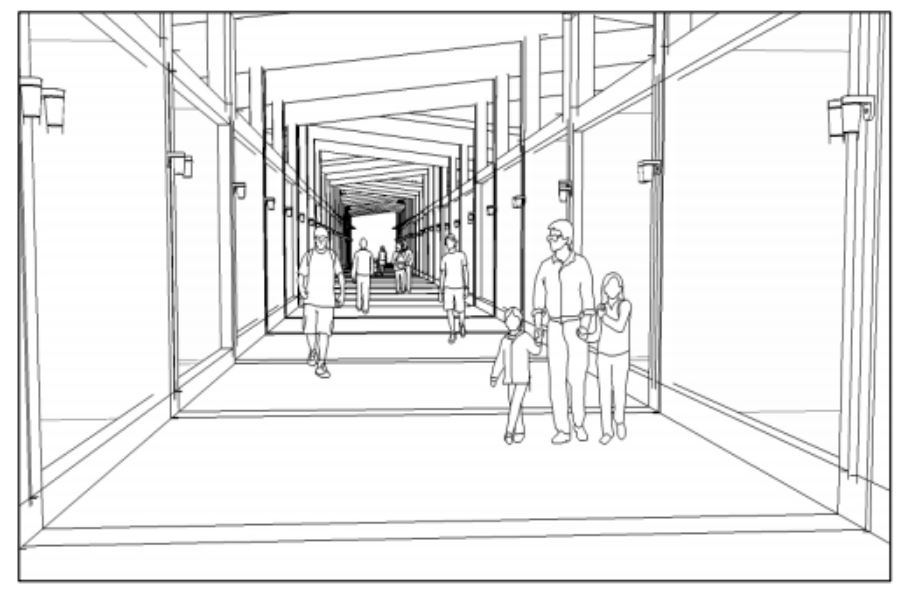

Gambar 5. Perspektif Green Pathway

Zeeger (1998) berpendapat, Cross Section Elements terdiri dari: (1) Lane Widths (Lebar Lajur Jalan). Lebar Lajur Jalan dapat mempengaruhi kenyamanan dan keselamatan bagi pengguna jalan (pedestrian and vehicle). Jalur sempit (10 atau 11 kaki) tidak boleh digunakan ketika pejalan kaki dan kendaraan sama-sama menggunakan; (2) Shoulders (Bahu Jalan). Bahu jalan bukan hanya tempat pemberhentian kendaraan melainkan INERSIA, Vol. XIV No. 1, Mei 2018 elemen struktur yang mendukung lateral jalan. Bahu jalan biasanya sering digunakan oleh pejalan kaki. Namun secara teori bahu jalan bukanlah pengganti pedestrian ways; (3) Curbs (Kereb). Kereb adalah bagian dari jalan berupa struktur vertikal dengan bentuk tertentu yang digunakan sebagai pelengkap jalan untuk memisahkan badan jalan dengan fasilitas lain, seperti jalur pejalan kaki, median, separator, maupun tempat parkir. (Standar Nasional Indonesia, 
2442:2008 tentang spesifikasi kereb beton untuk jalan); (4) Walkways (Trotoar). Jalur pejalan kakiyang umumnya sejajar dengan jalan dan lebih tinggi dari permukaan perkerasan jalan untuk menjamin keamanan pejalan kaki; (5) Traffic Barriers, adalah pembatas/ penghalang pada sisi jalan agar mencegah kendaraan masuk ke dalam tebing/ lereng/ sungai. (6) Medians, adalah suatu pemisah fisik jalur lalu lintas yang berfungsi untuk menghilangkan konflik lalu lintas dari arah yang berlawanan, sehingga pada gilirannya akan meningkatkan keselamatan lalu lintas. SNI 03-6967-2003 tentang Persyaratan Umum Sistem Jaringan dan Geometrik Jalan Perumahan dapat dijelaskan, bagianbagian jalan terdiri dari: Damija (Daerah Milik Jalan), Damaja (Daerah Manfaat Jalan), Dawasja (Daerah Pengawasan Jalan), Jalur dan Lajur Jalan, Bahu dan Trotoar, Saluran dan Drainase, serta Median Jalan. Secara lengkap bagian jalan dapat dilihat pada gambar di bawah ini.
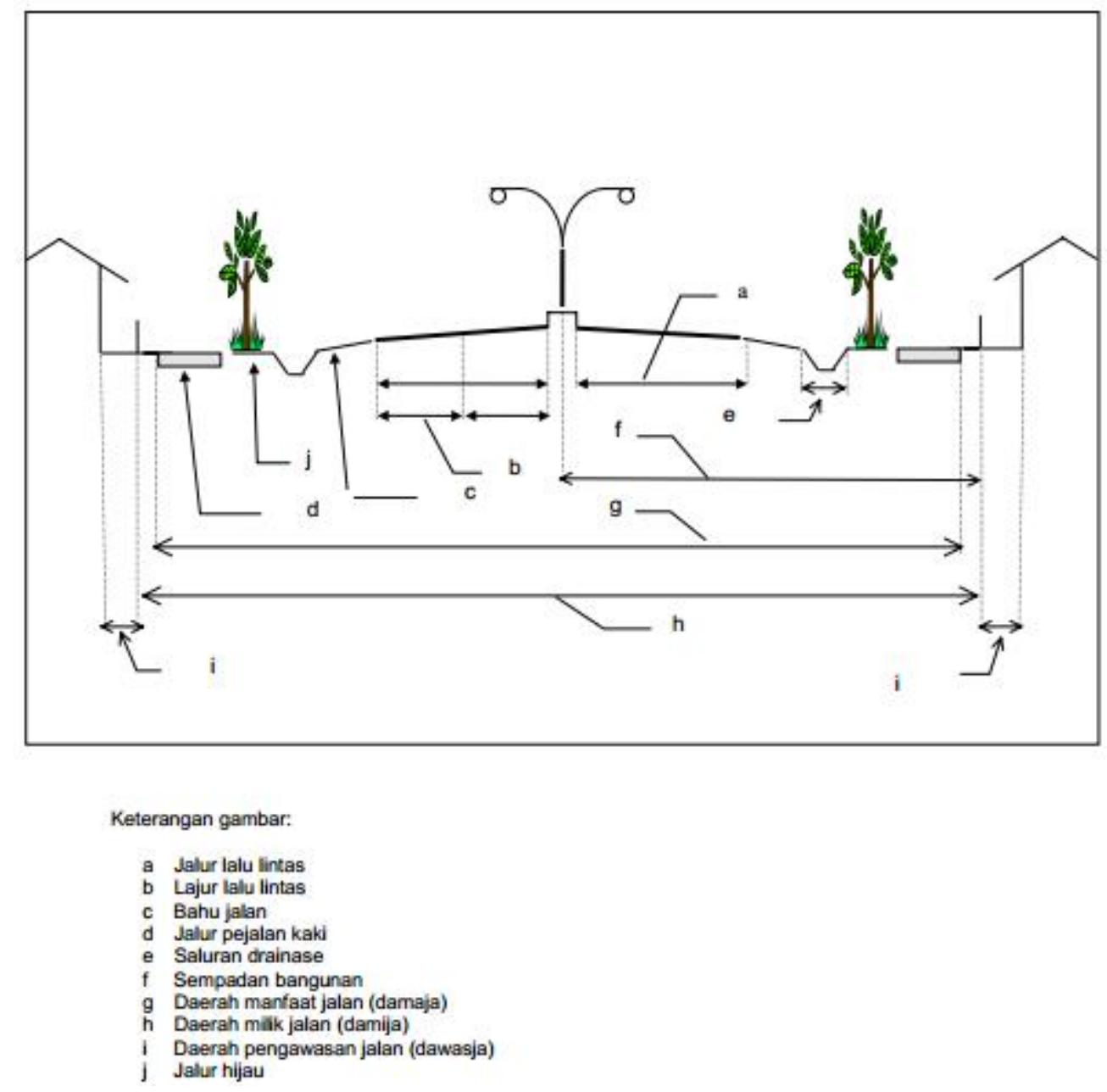

Gambar 6. Bagian-bagian Jalan

Secara umum terdapat beberapa faktor yang berperan dalam tingkat pelayanan pada fasilitas pedestrian ways (Highway Capital Manual, 1985) yaitu: (1) Kenyamanan (comfort), seperti pelindung terhadap cuaca, arcade, halte angkutan umum dan sebagainya. (2) Kenikmatan (convenience), seperti jarak berjalan, tanda- tanda petunjuk dan sebagainya yang membuat perjalanan lebih menyenangkan. (3) Keselamatan (safety), disediakan dengan memisahkan pejalan dengan lalu lintas kendaraan seperti mall dan kawasan bebas kendaraan lainnya dan sebagainya. (4) Keamanan(security), termasuk lampu lalu lintas, pandangan yang tidak terhalang 
Penataan Sistem Jalur... (Muhammad Aghpin/ hal. 101 - 117)

ketika menyeberang dan tingkat atau tipe dari jalan. (5) Aspek ekonomi yang berkaitan dengan biaya pengguna yang berhubungan dengan tundaan perjalanan dan ketidaknyamanan. Zeeger (1998) dalam Design and Safety of Pedestrian Facilities pada bab Pedestrian with Disabilitiesada 9 komponen pedestrian ways yang perlu diperhatikan untuk penyandang cacat, yaitu: sidewalks, street furniture, stairways, parking, curb cuts and ramps, bus Stops, signing, overpasses/underpasses, and construction sites.

Pedoman Teknik Persyaratan Aksesibiltas pada Jalan Umum (Departemen Pekerjaan Umum tahun 1999) dapat dijelaskan, persyaratan teknik penerapan prasarana aksesibilitas dibagi menjadi: Prasarana Aksesibilitas pada Jalur Trotoar/ Jalur Pejalan Kaki. Persyaratan teknik yang harus diperhatikan dalam perencanaan jalur pejalan kaki adalah: (1) Tingkat kenyamanan pejalan kaki yang optimal, seperti faktor kelandaian dan jarak tempuh serta rambu-rambu petunjuk pejalan kaki.

(2) Jalur pejalan kaki sebaiknya ditempatkan jauh dari lalu lintas kendaraan sehingga keamanan pejalan kaki lebih terjamin, serta tersedianya prasarana pemberhentian bus dan dekat dengan prasarana umum lainnya. (3) Keamanan terhadap kemungkinan terjadinya benturan antara pengguna jalur pejalan kaki, terutama bagi penyandang cacat berkursi roda. (4) Penerangan yang cukup di malam hari sehingga memungkinkan jarak pandang yang cukup. (5) Hindari terjadinya hambatan-hambatan dan ketidaknyamanan berjalan kaki yang disebabkan oleh adanya pedagang kaki lima pada jalur pejalan kaki. (6) Jalur pejalan kaki dibuat sedemikian rupa sehingga pada waktu hujan permukaannya tidak licin dan tidak terjadi genangan air serta disarankan untuk dilengkapi dengan pohon-pohon peneduh pada jalur tepinya. (7) Drainase sebaiknya dibuat tegak lurus dengan arah jalan dengan lubang yang dijauhkan dari tepi jalur penghubung (ramp) sehingga tidak mendatangkan bahaya. (8) Tepi jalur penghubung (ramp) dan batas pegangan (hand railing) bagi tongkat tuna netra. Penting adanya tepi jalur penghubung (ramp) untuk penghentian roda bagi pemakai kursi roda dan pegangan (hand railing) bagi tongkat tuna netra kea rah daerah yang berbahaya. Penyetop dibuat setinggi minimum $0,1 \mathrm{~m}$ dan lebar $1,5 \mathrm{~m}$ sepanjang jalur pejalan kaki.

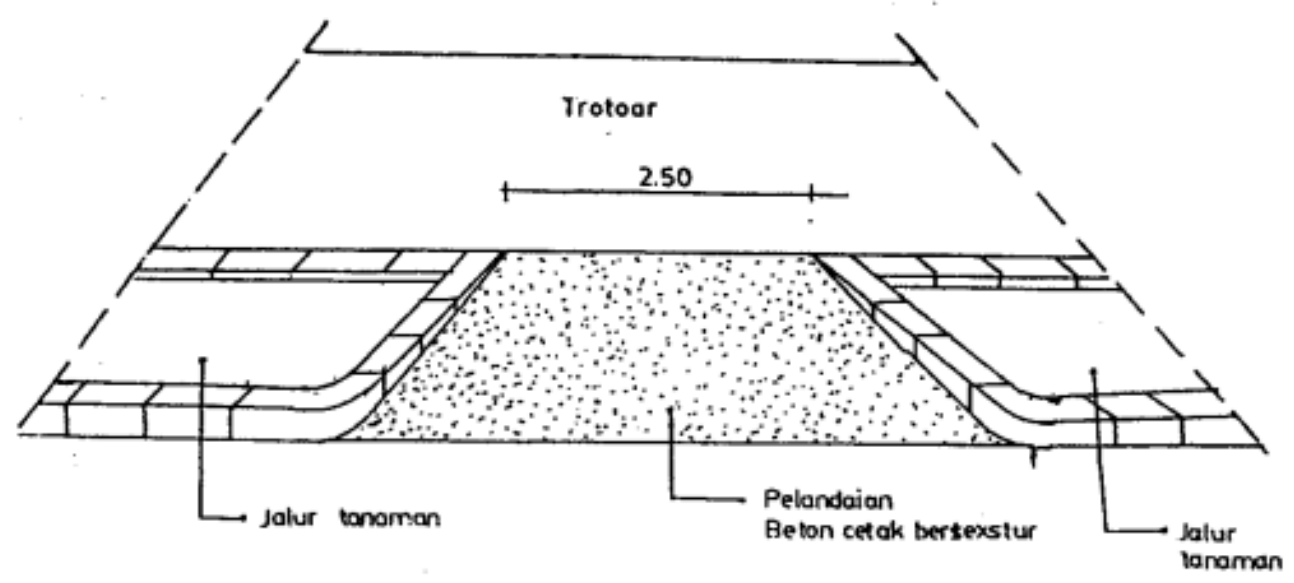

Gambar 7. Pelandaian Trotoar untuk Penyandang Cacat

Prasarana Aksesibilitas pada Tempat Penyeberangan. Tempat Penyeberangan
Sebidang, Zebra Cross. Penyeberangan Zebra (Zebra Crossing) harus dipasang 
pada jalan yang volume lalu lintasnya rendah, yaitu antara 200 - 500 kendaraan/ jam dengan volume pejalan kaki yang menyeberang kurang dari 100 orang/ jam. Penyeberangan Zebra pada umumnya dipasang pada jalan non arteri, dimana tundaan kendaraan yang diakibatkan oleh penggunaan prasarana penyeberangan masih dalam batas yang aman. Untuk menghubungkan dengan Daerah Manfaat Jalan, dirancang jalur penghubung (ramp access) yang dapat dilihat pada gambar di bawah ini.

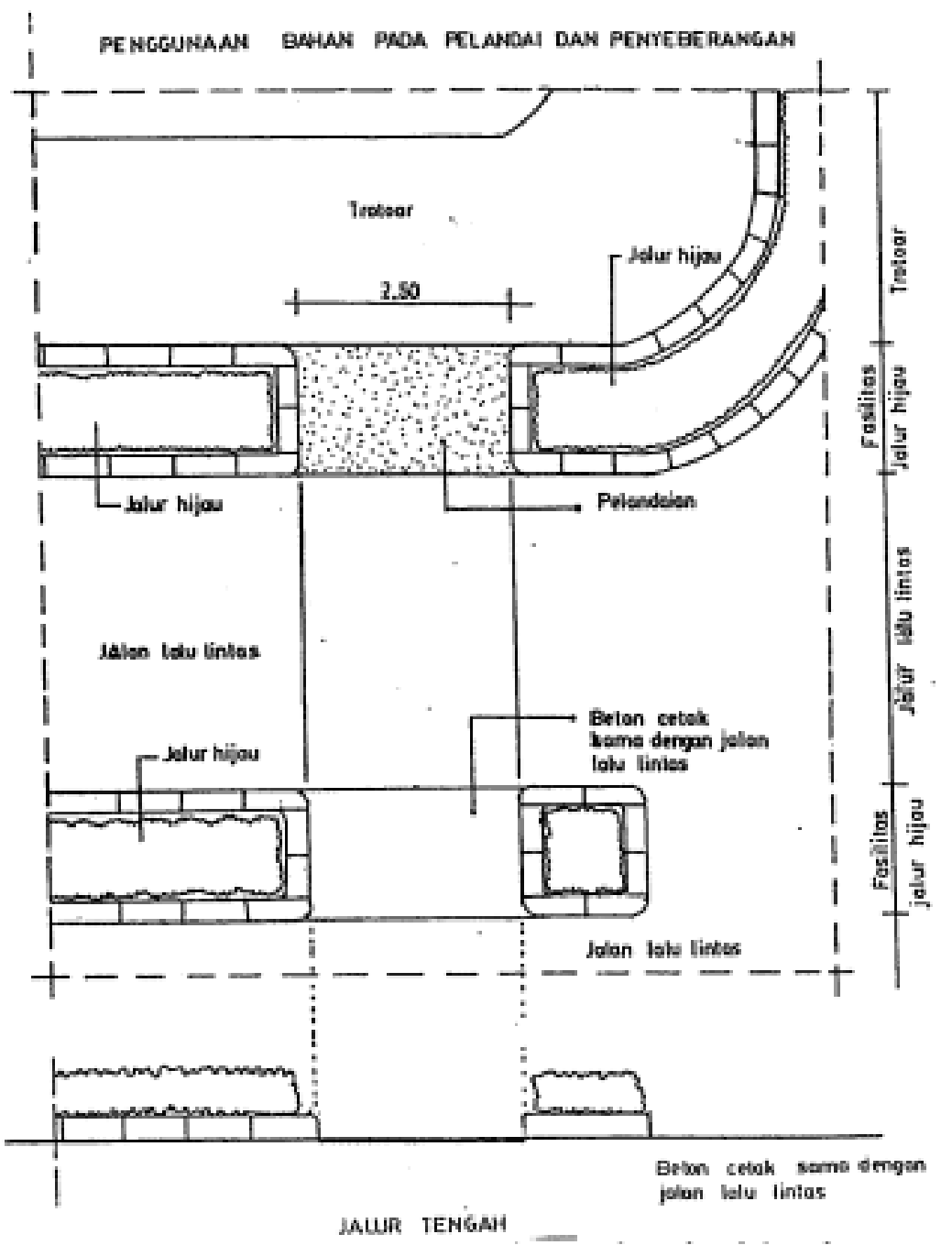

Gambar 8. Penggunaan Bahan pada Pelandaian dan Penyeberangan

Penyeberangan Pelican harus dipasang pada lokasi-lokasi sebagai berikut: (1) Pada jalur lalu lintas kendaraan dengan kecepatan tinggi; (2) Pada daerah/ kawasan dimana volume penyeberangan tinggi; (3) Persimpangan yang menggunakan alat pemberi isyarat lalu lintas, dimana Penyeberangan Pelican dapat dipasang menjadi satu kesatuan dengan rambu lalu lintas (traffic sign); (4) Untuk membantu para tuna netra, penyeberangan pelican dilengkapi dengan suara/ bunyi yang terintegrasi dengan alat pemberi isyarat lalu lintas.

Lapak tunggu harus dipasang pada jalur lalu lintas yang lebar, dimana penyeberangan jalan sulit untuk menyeberang dengan aman, terutama bagi penyendang cacat yang menggunakan alat. Lebar lapak tunggu minimum adalah 1,20 $\mathrm{m}$, tegak lurus kepada permukaan melintang jalan, dan terletak pada median jalan. Lapak tunggu harus dicat dengan cat yang memantulkan cahaya. Bagi kepentingan aksesibilitas, lapak tunggu INERSIA, Vol. XIV No. 1, Mei 2018 
Penataan Sistem Jalur... (Muhammad Aghpin/ hal. 101 - 117)

dibuat tanpa peninggian sehingga elevasi permukaan perkerasannya sama dengan jalur lalu lintas.

Tempat penyeberangan tidak sebidang yang dipersiapkan sebagai prasarana aksesibilitas adalah dengan menggunakan jembatan penyeberangan. Pembangunan jembatan penyeberangan disarankan memenuhi ketentuan sebagai berikut: (1) Bila penyeberangan dengan menggunakan prasarana dengan biaya murah seperti penyeberangan zebra sudah tidak dapat mengatasi masalah yang ada. (2) Pada ruas jalan dimana frekuensi terjadinya kecelakaan yang melibatkan pejalan kaki cukup tinggi. (3) Pada ruas jalan yang mempunyai volume lalu lintas dan volume pajalan kaki yang tinggi. (4) Dibangun Jalur Penghubung (ramp access) yang landai untuk memudahkan para pemakai. Apabila tidak tersedia cukup ruang untuk ini maka disarankan menggunakan lift.

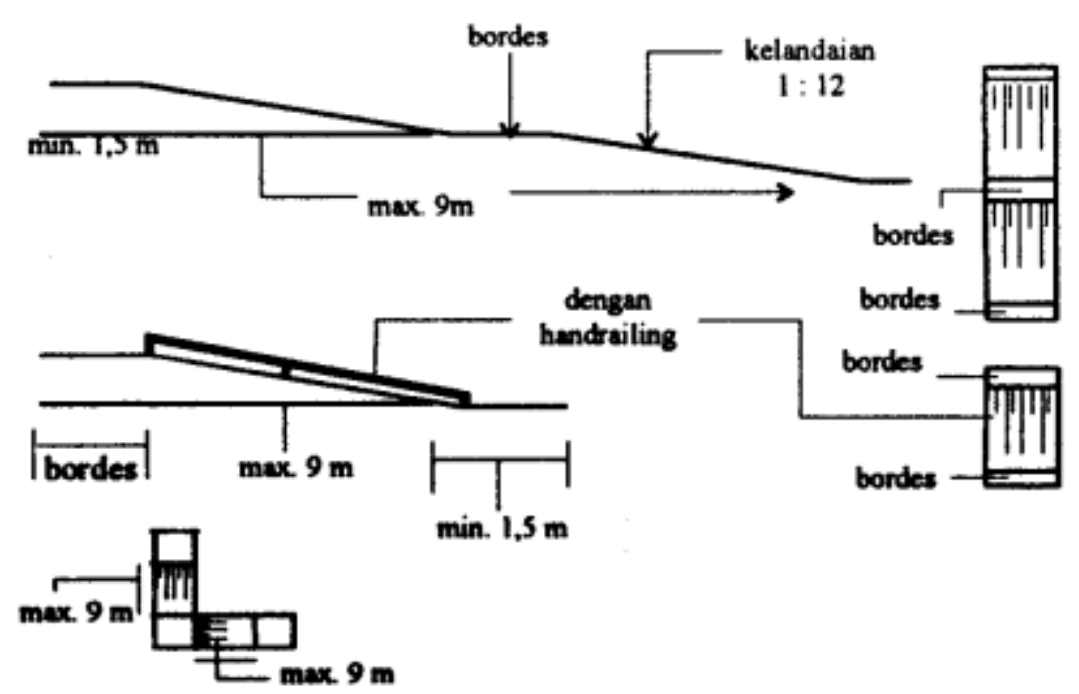

Gambar 9. Pelandaian Jalur Penghubung (Ramp Access) pada Tangga Penyeberangan

\begin{tabular}{|c|c|}
\hline 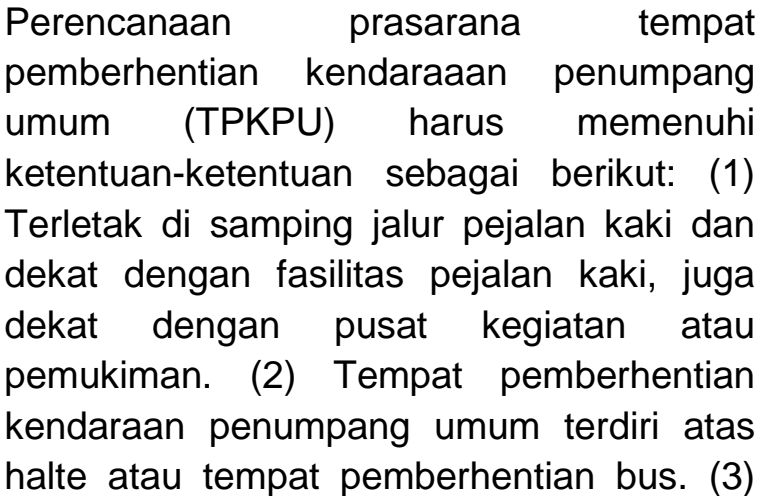 & $\begin{array}{l}\text { kendaraan penumpang umum untuk } \\
\text { menurunkan dan/ atau menaikkan } \\
\text { penumpang yang dilengkapi dengan } \\
\text { bangunan. (4) Tempat pemberhentian bus } \\
\text { (bus stop) adalah tempat untuk menurunkan } \\
\text { dan/ atau menaikkan penumpang yang } \\
\text { dilengkapi dengan atau tanpa bangunan. (5) } \\
\text { Teluk bus (bus bay) adalah bagian } \\
\text { perkerasan jalan tertentu yang diperlebar } \\
\text { dan diperuntukkan sebagai TPKPU. }\end{array}$ \\
\hline
\end{tabular}
Halte adalah tempat pemberhentian 


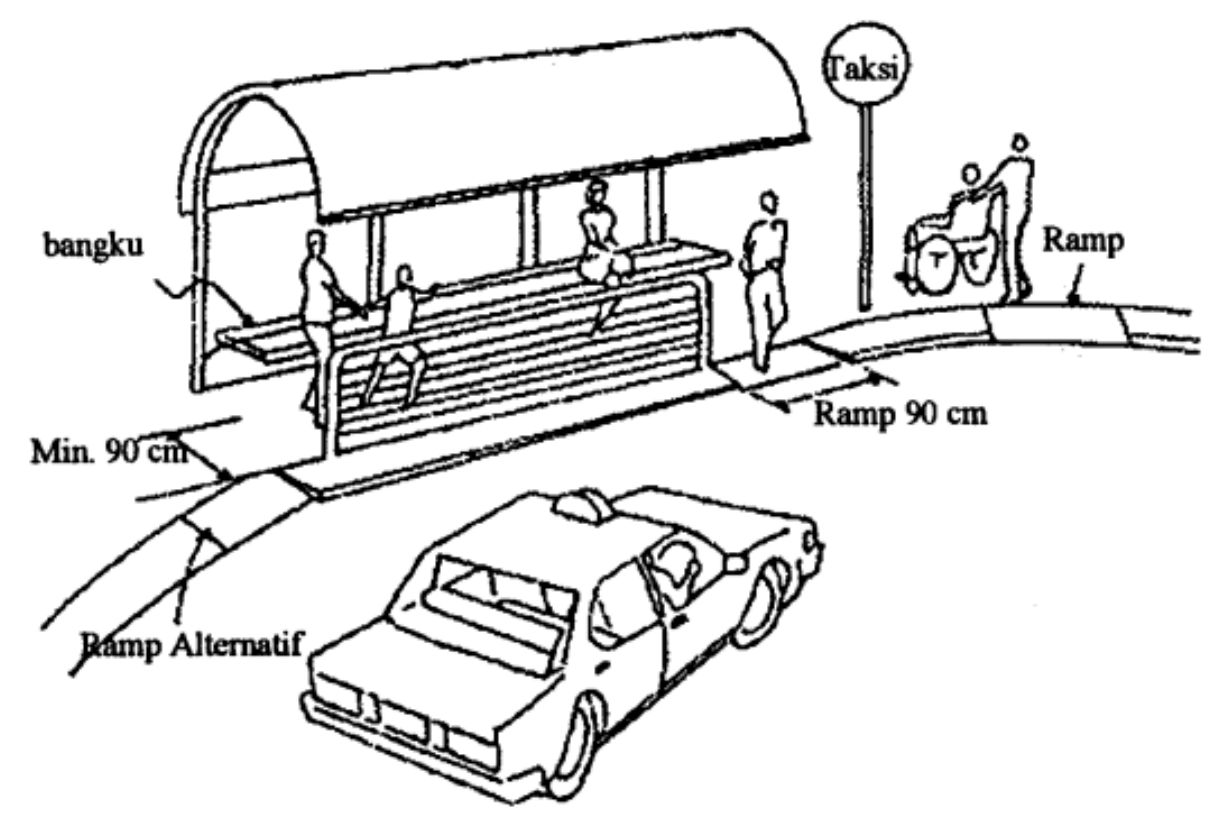

Gambar 10. Desain Prasarana Aksesibilitas pada Tempat Pemberhentian Kendaraan Umum

Tempat parkir bagi aksesibilitas pada lokasi-lokasi tertentu dapat diletakkan berdampingan dengan badan jalan dengan mengikuti ketentuan berikut.

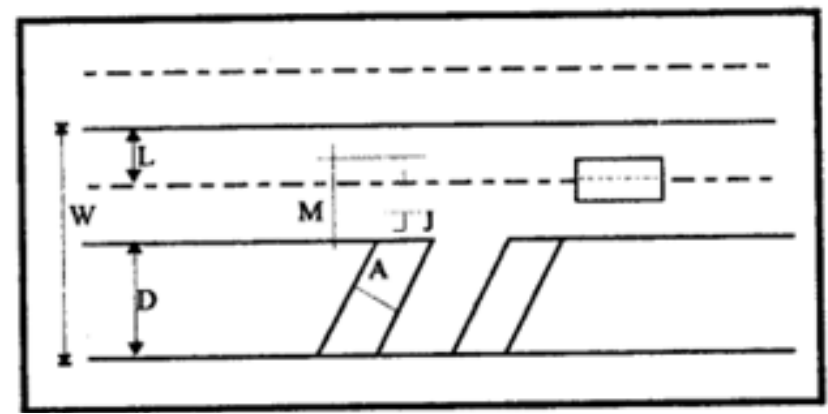

Keterangan :

$$
\begin{aligned}
& A=\text { Lebar ruang parkir }(\mathrm{m}) \\
& \mathrm{D}=\text { Ruang parkir efektif }(\mathrm{m}) \\
& \mathrm{M}=\text { Ruang Manuver }(\mathrm{m}) \\
& \mathrm{J}=\text { Lebar pengurangan ruang manuver }(\mathrm{m}) \\
& \mathrm{W}=\text { Lebar total jalan } \\
& \mathrm{L}=\text { Lebar jalan efektif }
\end{aligned}
$$

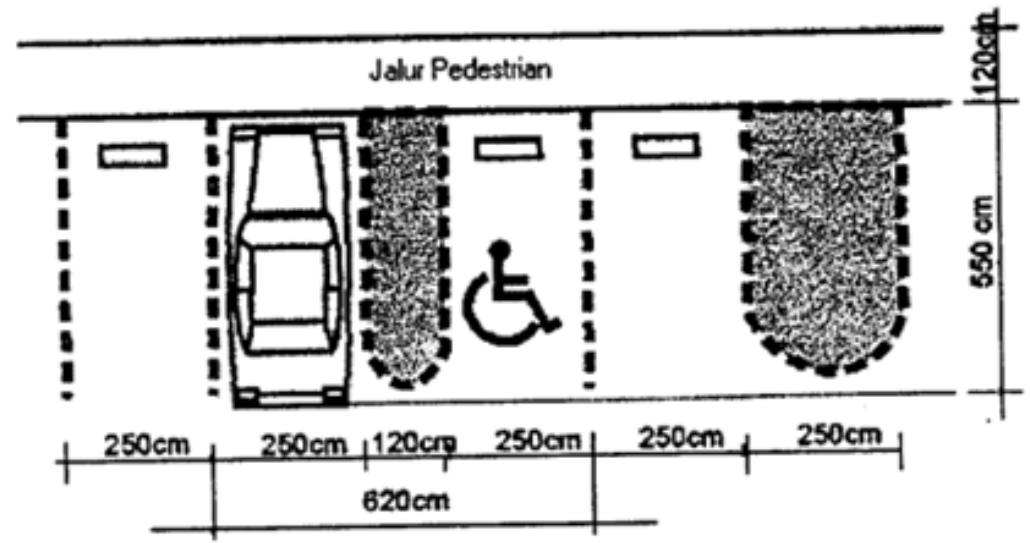

Gambar 11. Desain Prasarana Aksesibilitas pada Tempat Parkir 


\section{METODE}

Metode yang digunakan dalam kajian ini adalah deskriptif kuantitaif dengan cara membandingkan kriteria standar Ruang Terbuka dengan kondisi realita. Teknik pengumpulan data melalui observasi dan pengukuran dimensi bangunan. Kajian ini membagi wilayah UNY menjadi 6 zona. Dasar pengelompokkan zona melalui tinjauan fisik yaitu jalan yang memisahkan beberapa Fakultas yang terdapat di UNY. Setiap zona terdiri dari beberapa kluster berdasarkan pada kelompok pembagian zona, berikut nama-nama gedung berdasarkan dari pembagian zona, antara lain: a) zona A meliputi Fakultas Teknik, gedung LPPM, gedung LPPMP, b) zona B meliputi Fakultas Ekonomi, Fakultas IImu Sosial, Fakultas IImu Pengetahuan, Dekanat Fakultas Matematika dan IImu Pengetahuan Alam, Museum Pendidikan, Koperasi Mahasiswa, gedung lama Program Pascasarjana, c) zona C meliputi Student Center, Fakultas Bahasa dan Seni, FMIPA, dan komplek Masjid Mujahidin, d) zona D meliputi Gor UNY dan sekitarnya e) zona $\mathrm{E}$ meliputi Lapangan UNY, Fakultas IImu Keolahragaan, dan Wisma FIK, f) zona F meliputi Rektorat UNY, gedung baru Program Pascasarjana.

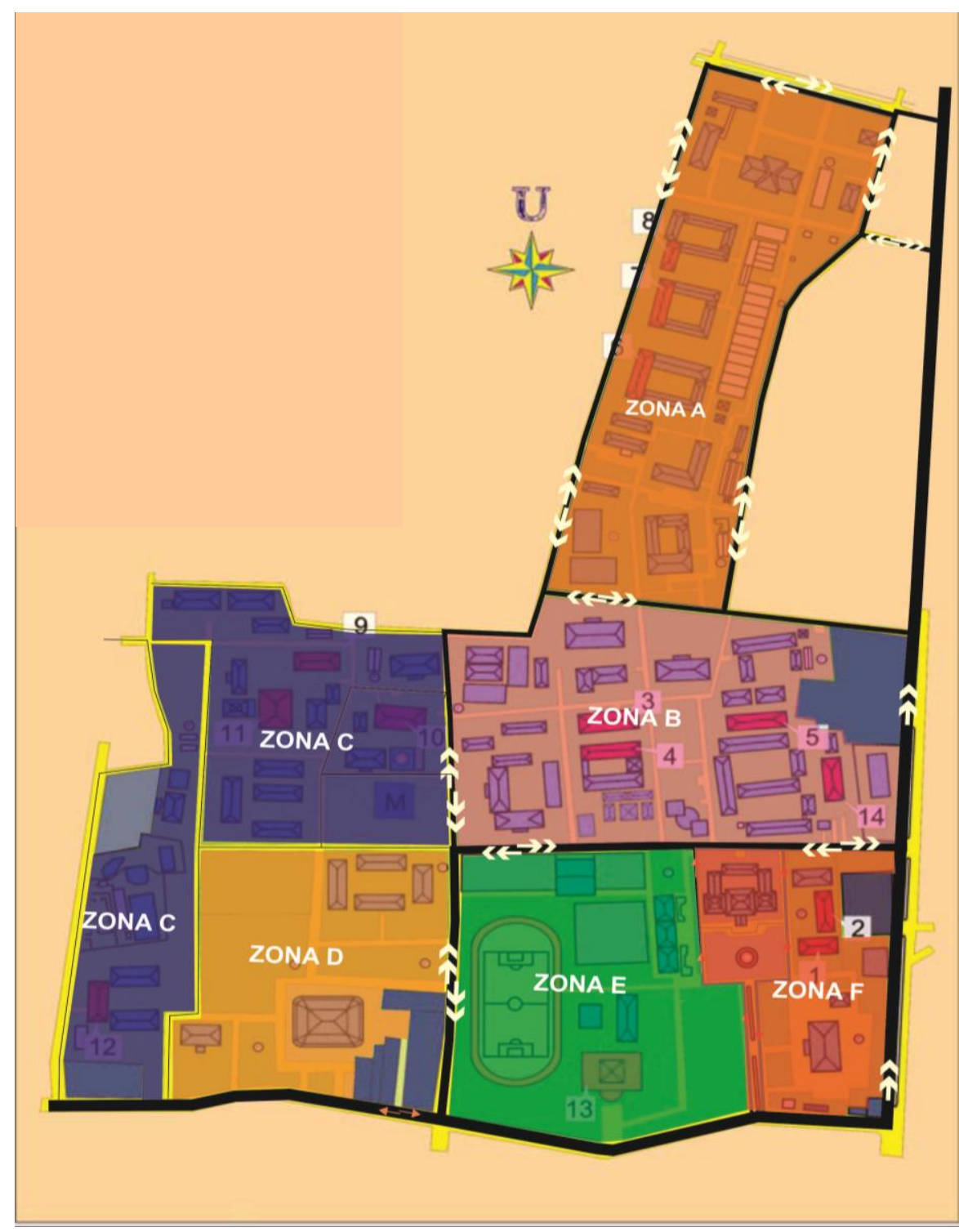

Gambar 12. Pembagian Zona di UNY 


\section{HASIL DAN PEMBAHASAN}

Dalam hal ini pedestrian ways di Universitas Negeri Yogyakarta dibagi menjadi empat tipe yaitu: Tipe 1 (Separated): Trotoar/ side walk; Tipe 2 (Integration): Pedestrian ways menggunakan jalan umum; Tipe 3 (Car dominant): Pedestrian ways menggunakan jalan umum, namun kendaraan lebih dominan; Tipe 4 (Corridor): Meliputi koridor, jalan penghubung antar gedung. Kendaraan dilarang melewati jalur ini.

Adapun permasalahan umum pedestrian ways di UNY adalah belum terintegrasinya jalur pejalan kaki baik antar zona maupun antar kluster, di beberapa titik khususnya pedestrian ways tipe 2 belum jelas pemisah antara jalan umum (street) dengan jalur pejalan kaki, dan belum lengkapnya tanda (sign) pada jalur pejalan kaki. Adapun permasalahan khusus pedestrian ways di UNY adalah dimensi/ ukuran pedestrian ways yang belum ideal di zona $B$, dan minimnya fasilitas jalur pedestrian ways.

Penataan sistem pedestrian ways yang terintegrasi. Sistem pedestrian ways UNY yang terdiri dari jalan pusat dan jalan penghubung. Jalan pusat pedestrian ways membentang dari selatan ke utara (rektorat sampai ke FT) dan dari timur ke barat (jalan guru sampai ke FIK). Sedangkan jalan penghubung pedestrian ways menghubungkan antar kluster dan antar area parkir khususnya. Perencanaan Jalur
Pejalan Kaki, lebar standar (dimensi/ ukuran pedestrian ways), untuk mengetahui lebar standar pedestrian ways, dalam hal ini adalah trotoar/side walk, digunakan rumus:

$\mathrm{W}=\frac{v}{35}+N$

Keterangan:

$\mathrm{W}=$ lebar trotoar (meter)

$\mathrm{V}=$ volume pejalan kaki rencana/ dua arah

(orang/ meter/ menit)

$\mathrm{N}$ = lebar tambahan sesuai dengan

keadaan setempat (meter)

Volume pejalan kaki (V) didapat dengan melakukan pengamatan pada trotoar di zona B (di depan Kopma). Pencatatan dilakukan setiap interval 15 menit selama enam jam paling sibuk dalam satu hari. Karena keterbatasan SDM, maka data V diasumsikan selama 15 menit pejalan kaki yang melewati trotoar tersebut adalah 4 orang.

menit

15 menit $\rightarrow V=4$ orang/ meter/

60 menit $\rightarrow V=16$ orang/ meter/ menit

360 menit $\rightarrow \mathrm{V}=96$ orang/ meter/ menit

Lebar tambahan $(\mathrm{N})$ berdasarkan Petunjuk Perencanan Trotoar No.007/T/BNKT/1990 Direktorat Pembinaan Jalan Kota adalah

Tabel 1. Ukuran Lebar Tambahan

\begin{tabular}{cl}
\hline $\mathbf{N}$ (meter) & \multicolumn{1}{c}{ Keadaan } \\
\hline 1,5 & Jalan di daerah pasar \\
1,0 & Jalan di daerah perbelanjaan bukan pasar \\
0,5 & Jalan di daerah lain \\
\hline
\end{tabular}

Dari tabel di atas, digunakan $\mathrm{N}=0,5$ meter, sehingga $W=\frac{96}{35}+0,5=3,2$ meter. Berdasarkan perhitungan di atas, lebar trotoar (W) yang sesuai standar ideal pada zona B adalah 3,2 meter. Sedangkan 112 berdasarkan pada Petunjuk Perencanaan Trotoar, lebar minimum pada penggunaan lahan institusi pendidikan (sekolah) adalah 2 meter. Seperti yang ditunjukkan pada tabel di bawah ini.

INERSIA, Vol. XIV No. 1, Mei 2018 
Tabel 2. Lebar minimum trotoar menurut penggunaan lahan sekitarnya

\begin{tabular}{clc}
\hline & Penggunaan Lahan sekitarnya & Lebar minimum $\mathbf{( m )}$ \\
\hline 1. & Perumahan & 1,5 \\
2. Perkantoran & 2,0 \\
3. Industri & 2,0 \\
4. Sekolah & 2,0 \\
5. Terminal/ Stop Bus & 2,0 \\
6. Pertokoan/ Perbelanjaan & 2,0 \\
7. Jembatan/ Terowongan & 1,0 \\
\hline (Sumber: Petunjuk Perencanaan Trotoar No.007/T/BNKT/1990 Dir.Pembinaan Jalan Kota)
\end{tabular}

Ukuran tinggi trotoar, berdasarkan Peraturan PU trotoar harus ditinggikan setinggi kerb. Menurut Kroemer (1994) ketinggian kerb trotoar dipersyaratkan maksimal $10 \mathrm{~cm}$. Pada kenyataannya, tinggi trotoar yang berada pada zona B (depan kopma) sebesar $\pm 25 \mathrm{~cm}$. Sehingga sebagai alternatif solusi tinggi trotoar tidak lebih dari $10 \mathrm{~cm}$. Perbandingan ketersediaan pedestrian ways dengan kepadatan populasi. Data yang diperlukan: luas pedestrian ways yang tersedia di zona $A$ dan jumlah mahasiswa aktif dalam 1 hari.

Tabel 3. Perhitungan Ketersediaan Pedestrian Ways di Zona A

\begin{tabular}{lccc}
\hline \multicolumn{1}{c}{ Nama Kluster } & Panjang $(\mathbf{m})$ & Lebar $(\mathbf{m})$ & Luas $_{\left(\mathbf{m}^{2}\right)}$ \\
\hline KPLT dan sekitarnya & 414 & 2 & 828 \\
\hline $\begin{array}{l}\text { Jurusan Sipil, Mesin, } \\
\text { Elektro }\end{array}$ & 348 & 4 & 1392 \\
\hline Dekanat lama & & & 1066 \\
\hline LPMP dan sekitarnya & 333 & 2 & 624 \\
\hline TOTAL & 312 & 2 & 3910 \\
\hline
\end{tabular}

Guna mengetahui jumlah mahasiswa aktif di zona A dalam 1 hari dilakukan dengan 2 pendekatan perhitungan. Pertama, menjumlahkan mahasiswa aktif FT dibagi hari aktif kuliah. Kedua, mendata total kelas dan lab masing-masing jurusan, kemudian mengasumsikan jika kelas dan lab terisi penuh. Secara detail dijelaskan pada perhitungan di bawah ini. Pendekatan pertama, tabel Jumlah mahasiswa FT aktif per Desember 2017.

Tabel 4. Jumlah Mahasiswa FT Aktif per Desember 2017

\begin{tabular}{lr}
\hline \multicolumn{1}{c}{ Jurusan } & Jumlah \\
\hline Teknik Sipil & 667 \\
\hline Teknik Mesin & 1616 \\
\hline Teknik Elektro & 2129 \\
\hline PTBB & 1302 \\
\hline TOTAL & 5714 \\
\hline (Sumber: Laporan Tahunan UNY 2017) &
\end{tabular}

Total mahasiswa FT aktif dibagi hari aktif kuliah, sehingga $\frac{5714}{5}=1143$ orang/ hari.
Pendekatan kedua, dengan jumlah kelas dan lab/bengkel di FT. 
Tabel 5. Jumlah Kelas, Lab dan Bengkel di FT.

\begin{tabular}{|c|c|c|c|c|c|c|}
\hline Jurusan & $\begin{array}{l}\text { Jumlah } \\
\text { Kelas }\end{array}$ & $\begin{array}{l}\text { Daya } \\
\text { Tampung } \\
\text { Kelas }\end{array}$ & $\begin{array}{c}\text { Jumlah } \\
\text { mahasiswa }\end{array}$ & $\begin{array}{l}\text { Jumlah } \\
\text { lab }\end{array}$ & $\begin{array}{c}\text { Daya } \\
\text { Tampung } \\
\text { Lab/bengkel }\end{array}$ & $\begin{array}{c}\text { Junlah } \\
\text { mahasiswa }\end{array}$ \\
\hline Teknik Sipil & 5 & 40 & 200 & 4 & 15 & 60 \\
\hline Teknik Mesin & 5 & 40 & 200 & 8 & 15 & 120 \\
\hline Teknik Elekro & 11 & 40 & 440 & 8 & 15 & 120 \\
\hline PTBB & 6 & 40 & 240 & 13 & 15 & 195 \\
\hline TOTAL & & & 1080 & & & 495 \\
\hline $\begin{array}{l}\text { TOTAL } \\
\text { KESELURUHA }\end{array}$ & & & $080+$ & 5750 & lari & \\
\hline
\end{tabular}

Dari kedua pendekatan di atas, diambil jumlah maksimum, yaitu sebesar 1.575 orang/ hari. Dengan demikian modul $\left(\mathrm{m}^{2} /\right.$ orang) pedestrian ways pada zona A adalah $\frac{3910}{1575}=2,48 \mathrm{~m}^{2} /$ orang. Dengan mengetahui nilai modul, kita dapat mengetahui ingkat pelayanan trotoar dengan bantuan tabel di bawah ini.

Tabel 6. Tabel Tingkat Pelayanan Trotoar

\begin{tabular}{ccc}
\hline Tingkat Pelayanan & Modul $\left(\mathbf{m}^{2} /\right.$ orang) & Volume (orang/ meter/ menit) \\
\hline A & $\geq 3,25$ & $\leq 23$ \\
B & $2,30-3,25$ & $23-33$ \\
C & $1,40-2,30$ & $33-50$ \\
D & $0,90-1,40$ & $50-66$ \\
E & $0,45-0,90$ & $66-82$ \\
F & $\leq 0,45$ & $\geq 82$ \\
\hline
\end{tabular}

(Sumber: Petunjuk Perencanaan Trotoar No.007/T/BNKT/1990 Dir.Pembinaan Jalan Kota)

Berdasarkan tabel di atas, pedestrian ways di zona $A$ berada pada tingkat pelayanan $B$. $\mathrm{Hal}$ ini berarti pedestrian ways di zona $\mathrm{A}$ termasuk kategori ideal (serendah- rendahnya tingkat pelayanan C) dan telah mampu melayani warga kampus yang berada di zona $\mathrm{A}$. 


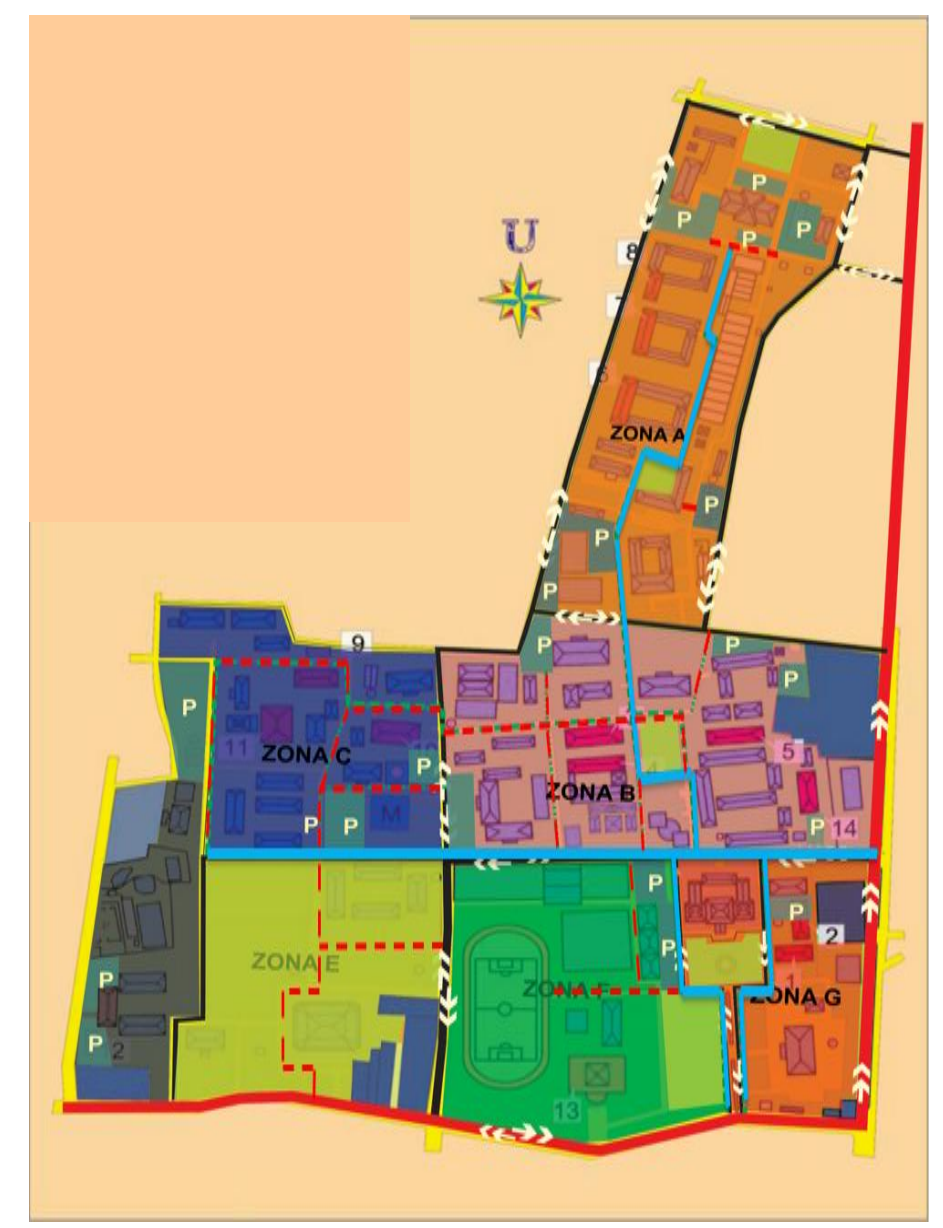

Gambar 13. Desain Usulan Pedestrian Ways yang terintegrasi

Keterangan:

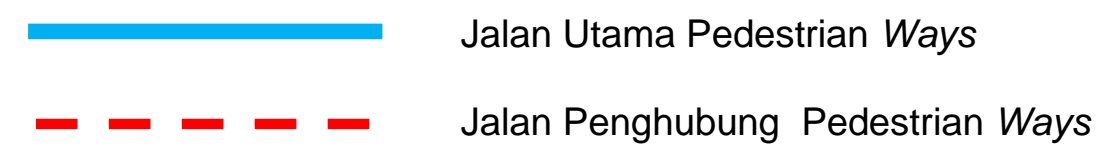

Desain usulan Pedestrian Ways di UNY adalah pedestrian ways yang terintegrasi baik antar zona maupun antar kluster, sehingga menghubungkan dengan area parkir, land mark, jalan kendaraan, dan tetap memperhatikan aspek open space. Pada jalan utama pedestrian ways terbentang dari selatan kampus (rektorat) hingga ke utara kampus (FT) dan dari timur kampus (jalan guru) hingga ke barat kampus (FIK). Jalan utama di utara melewati zona $F$ (jalan masuk dari Colombo, gedung rektorat, dan gedung baru PPs) kemudian masuk ke zona B (Museum Pendidikan, Taman Pancasila, FE, dan LPMP), menuju ke utara zona $A$
(Dekanat FT lama, jurusan-jurusan di FT, dan KPLT). Sedangkan jalan utama pedestrian ways dari arah timur kampus dimulai dari utara zona $B$ (jalan masuk dari Gejayan, PPs, Dekanat FMIPA), kemudian masuk ke zona C (FMIPA dan FIK).

Adapun jalan penghubung pedestrian ways, di zona A berada di belakang KPLT yang menghubungkan antara area parkir. Pada zona B di utara taman pancasila menuju ke arah barat (Hotel UNY dan belakang Kopma). Selain itu juga berada di timur Dekanat FMIPA ke arah utara menuju area parkir FE. Pada zona $C$, jalan penghubung pedestrian ways berada di utara Masjid 
Mujahiddin dan Garden Café. Kedua jalan penghubung tersebut bertemu di area FBS (Pendopo Tedjo). Arah selatan jalan tersebut masuk pada zona $D$ yang menghubungkan GOR UNY dan FIK. Pada zona $\mathrm{E}$ jalan peghubung pedestrian ways berada di selatan Perpustakaan menuju ke arah barat (Stadion) dan berada di timur Lapangan Tenis Indoor ke arah selatan dan bertemu dengan jalan penghubung sebelumnya. Desain Usulan Dimensi Trotoar pada zona B (depan Koperasi Mahasiswa UNY).

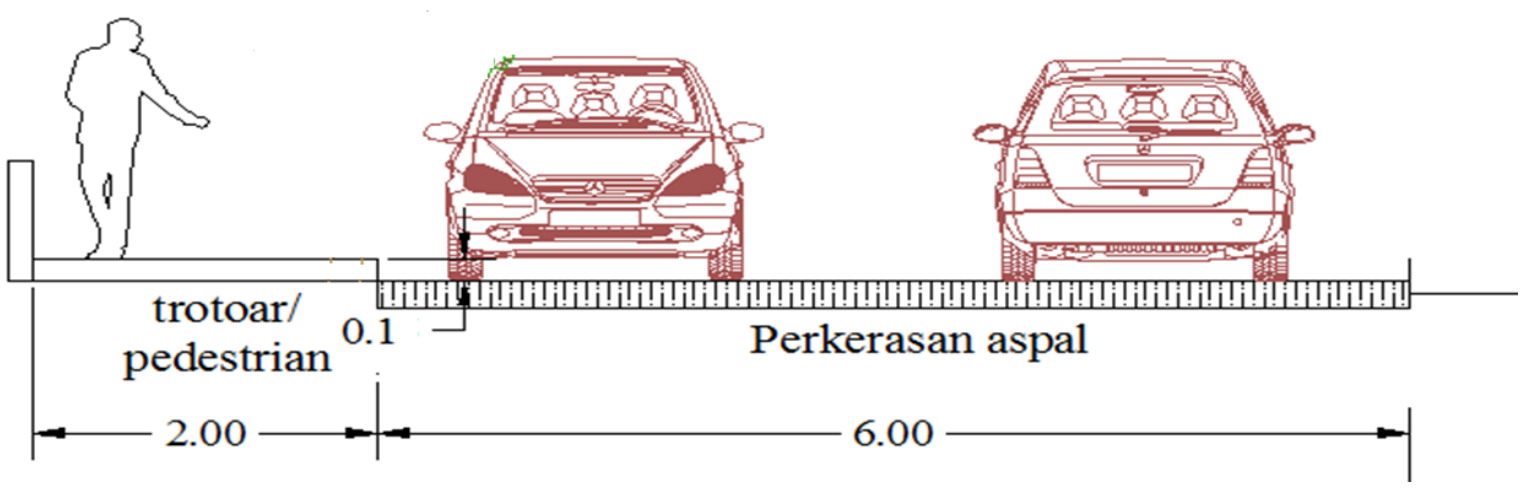

Gambar14. Desain Usulan Dimensi Trotoar pada zona B (depan Kopma)

Pada kenyataannya dimensi trotoar pada zona B (depan Kopma) memiliki lebar < 150 $\mathrm{cm}$ dan tinggi $\pm 25 \mathrm{~cm}$. Desain usulan yang diajukan adalahlebar minimal $200 \mathrm{~cm}$ dan tinggi maksimal $10 \mathrm{~cm}$. Dan pembatas di sepanjang trotoar dihilangkan karena dinilai tidak efektif terhadap para pejalan kaki. Sebagai alternatif dapat digunakan pembatas besi dengan tinggi $50 \mathrm{~cm}$.

\section{SIMPULAN}

Hasil kajian menunjukkan bahwa: Pembagian zona secara fisik di kawasan Kampus UNY terdiri dari 6 zona, yaitu: Zona A (FT, LPPMP, LPPM), Zona B (FE, FIS, Dekanat FMIPA, Kopma, PPs Lama, FIP), Zona C (FBS, FMIPA, Masjid Mujahiddin), Zona D (GOR UNY dan sekitarnya), Zona E (Stadion, Lapangan Tenis, FIK), dan Zona F (Rektorat, PPs Baru). Secara riil, ada 4 tipe pedestrian ways di UNY, yaitu: Tipe 1 (separated), Tipe 2 (integration), Tipe 3 (car dominant), dan Tipe 4 (corridor). Alternatif solusi atas permasalahan khusus dimensi dan ketersediaan (tingkat pelayanan) trotoar yaitu dimensi trotoar yang berada di zona $B$ belum ideal, sedangkan trotoar pada zona $A$ sudah cukup tersedia.

\section{DAFTAR RUJUKAN}

Kroemer, K.H.E; Kroemer, H.B.; KroemerEbert, K.E. (1994). Ergonomics, How to Design for Ease and Effiviency. Prentice Hall International, Inc.

Pedoman Penyediaan dan Pemanfaatan Prasarana dan Sarana Ruang Pejalan Kaki di Perkotaan. (2012). Direktorat Penataan Ruang Departemen Pekerjaan Umum.

Pedoman Perencanaan Jalur Pejalan Kaki pada Jalan Umum. (1999). PT.Medisa Departemen Pekerjaan Umum.

Pedoman Teknik Persyaratan Aksesibiltas pada Jalan Umum. (1999). 
Penataan Sistem Jalur... (Muhammad Aghpin/ hal. 101 - 117)

PT.Medisa Departemen Pekerjaan Umum.

Petunjuk Perencanaan Trotoar No.007/T/BNKT/1990. (1990). Direktorat Pembinaan Jalan Kota Departemen Pekerjaan Umum.

Pratama, G. N. I. P., \& Hidayah, Retna. (2016). Evaluasi Pemanfaatan Ruang Terbuka Universitas Negeri Yogyakarta. Jurnal Inersia, XI(2), 95104.
SNI 03-6967-2003 tentang Persyaratan Umum Sistem Jaringan dan Geometrik Jalan Perumahan, Badan Standardisasi Nasional.

Tata Cara Perencanaan Fasilitas Pejalan Kaki di Kawasan Perkotaan. (1995). Direktorat Bina Teknik Departemen Pekerjaan Umum.

Zeeger, Charles V. (1998). Design and Safety of Pedestrian Facilities. Washington: Institute of Transportation Engineers. 